\title{
Performance of Barley (Hordeum vulgare L.) Varieties to Different Sowing Dates under Irrigated Conditions
}

\author{
Pawan Shivhare ${ }^{1}$, M. Devender Reddy ${ }^{2 *}$, Girish Pandey ${ }^{1}$ and Anuj Kumar ${ }^{1}$ \\ ${ }^{1}$ School of Agriculture, ITM University, Gwalior - 474001, (M.P.), India \\ ${ }^{2}$ M.S.Swaminathan School of Agriculture, Centurion University of Technology \\ and Management, Paralakhemundi, Odisha -761211, India \\ *Corresponding author
}

\begin{tabular}{l} 
Ke y w o r d s \\
Barley, Sowing \\
time, Varieties, \\
Irrigated conditions \\
\hline Article Info \\
\hline $\begin{array}{l}\text { Accepted: } \\
18 \text { March } 2020 \\
\text { Available Online: } \\
\text { 10 April } 2020\end{array}$ \\
\hline
\end{tabular}

A B S T R A C T
An experiment on performence of barley (Hordeum vulgare L.) varieties to different sowing dates under irrigated conditions was conducted at ITM University, Gwalior during rabi season 2015 -2016 with three dates of sowing ( 25 October, 5 and 15 November) and four varieties (NDB 2, NDB 3, NDB 1173and Super laxmi) in split plot design with three replications. The crop sown on 15 November recorded significantly higher grain number, weight of the spike, length of spike and 1000 grain weight over 5 November and 25 October sown crop. The varieties NDB-3 recorded significantly higher tiller number, effective tillers, number of grain per spike and 1000 grain weight over other varieties. The grain and straw yield was significantly higher with variety NDB 3 sown on 15 November as compared all other treatment combinations. The gross and net returns and B:C ratio were higher in the crop sown with variety NDB-3 on 15 November.

\section{Introduction}

In India, during TE 2016-17 barley is cultivated in about 0.65 million ha with a production of 1.60 million tones of grain and productivity of 2.46 tones $\mathrm{ha}^{-1}$ (WWW.Farmersfriend.info>Barly). The crop is mainly grown in Rajasthan, Uttar Pradesh, Haryana, Punjab, Madhya Pradesh and Bihar in plains, and Himachal Pradesh, Uttrakhand and Jammu and Kashmir in the hill states.
Sowing time depends on weather, topography and harvesting time of the preceding crops. Seeding of barley is done in early November in the medium highland areas particularly northern part of India.

In these water deficit areas, desertification is going on and agricultural production is very low but in the lowland areas, sowing is delayed even up to December because of the land is occupied by kharif Paddy. 
The differences in production of early and late sown crops may be due to favorable temperatures at different growth stages which may increase photosynthetic rate, assimilates the supply for seed and seed growth rate in early sown crops than late planting (Rashid et $a l ., 2010)$. Delayed planting decreases barley grain yield (Singh and Singh, 2005) while increasing grain protein content (Kavitha et al., 2012).

Under North Indian conditions, it's recommended sowing time of barley is from middle of October to middle of November (Anonymous, 2014). The differences in production of timely sown and late sown crops may be attributed to the unfavorable temperature prevailing at different growth stages, such as low temperature at the time of germination which may delay crop emergence. Low temperature may also slow down the growth and development of the crop, resulting in the accumulation of insufficient biomass and shortening of crop duration (Alam et al., 2006).

Systematic and intensive effort was made for development of varieties from 1967-68 through AICRP on barley. Since then number of cultivars were evolved and released for cultivation. However, the cultivars evolved for higher yield for different regions and their suitability for different regions needs to be tested.

Sowing at an appropriate time with suitable high yielding variety is necessary for ensuring maximum yield and that is why it needs to be adjusted so that crop germinates properly and utilize the stored soil moisture effectively. Enormous efforts are, therefore, needed in recommending proper sowing time. The present experiment was conducted to find out a suitable time of sowing and find out suitable barley varieties under irrigated conditions.

\section{Materials and Methods}

An investigation on Performence of barley (Hordeum vulgare L.) varieties to different sowing dates under irrigated conditions was conducted at ITM University, Gwalior (M. P.) during the Rabi season of 2015-16. The treatments were tested in split plot design with three replications consisting three sowing dates - 25 October, 05 November and 15 November (main plots) and four varieties - NDB-2, NDB-3, NDB-1175 and Super Laxmi (subplots).

The experiment site falls under humid subtropical climate and located in between $23^{\circ}$ $10^{\prime} \mathrm{N}$ latitude and $79^{\circ} 54^{\prime} \mathrm{E}$ longitudes at an elevation of 411.98 meters above mean sea level. The soil type of experimental field was sandy loam in nature with $\mathrm{pH}$ of 7.4 and EC $0.29 \mathrm{dsm}^{-1}$, having $242 \mathrm{~kg}$ available nitrogen, $20.5 \mathrm{~kg}$ available phosphorus and $456 \mathrm{~kg}$ available potassium.

During the crop growth period, the maximum temperature varied between $18.9^{\circ} \mathrm{C}$ in January third week to $40.1^{\circ} \mathrm{C}$ in April first week and minimum temperature ranged from $3.9^{\circ} \mathrm{C}$ in third week of December to $23^{\circ} \mathrm{C}$ in second week of April.

The experimental field was given a presowing irrigation and two ploughings were done by tractor and this was followed by planking each time and after this the field was laid out into plots with appropriate bunds between treatments. The crop was sown by using a seed rate of $100 \mathrm{~kg} \mathrm{ha}^{-1}$ with funnel attached to a desi plough, keeping row-to-row distance of $20 \mathrm{~cm}$. The sowing was done as per treatment dates. The seeds were covered by planking. The hand weeding was done after 10-12 days after first irrigation. After the hand weeding, the field remained free and clean from weeds. 
The fertilizers were applied at $60 \mathrm{~kg} \mathrm{~N}, 30 \mathrm{~kg}$ $\mathrm{P}_{2} \mathrm{O}_{5}$ and $20 \mathrm{~kg} \mathrm{~K} \mathrm{~K}_{2} \mathrm{O} / \mathrm{ha}$. The nitrogen was applied through urea and $\mathrm{P}_{2} \mathrm{O}_{5}$ and $\mathrm{K}_{2} \mathrm{O}$ were made through DAP and MOP. The full dose $\mathrm{P}_{2} \mathrm{O}_{5}$ and $\mathrm{K}_{2} \mathrm{O}$ and half dose on nitrogen were applied at the time of sowing time, and remaining half dose of urea was applied after first irrigation. Three irrigations were given at 30days after sowing (DAS), 70 DAS and grain filling stages.

All the agronomic management practices were done uniformly in all the treatments. The observations on plant height, numbers of tiller per meter row length and the yield contributing characters viz., ear head $\mathrm{m}^{-1}$ row length, spike length $(\mathrm{cm})$, number of spike lets spike ${ }^{-1}$, number of grains spike ${ }^{-1}$ and 1000 grains weight $(\mathrm{g})$ and the biological, grain and straw yields were recorded as per standard procedures.

The Harvest Index, the ratio of economic yield to the biological yield was calculated and expressed in per centage as given below:

$$
\text { Harvest Index }(\%)=\frac{\text { Economic yield (grain yield) }}{\text { Biologicalyield (grain }+ \text { straw) }} \times 100
$$

The data obtained on various observations were subjected to statistical analysis by using the techniques of the analysis of variance (ANOVA) and the treatment was tested by $\mathrm{F}$ test and Critical difference (CD) at 5\% level of significance (Panse and Sukhatme, 1989) for each character to compare the differences among treatment means.

\section{Results and Discussion}

\section{Dates of sowing}

\section{Growth}

The plant stand recorded at initial stage was not affected significantly due to dates of sowing. At maturity, the plant height observed with 15 November sowing was significantly higher over 05 November sown crop which in turn recorded significantly higher plant height over 25 October sown crop (Table 1).

At harvest, the tiller number per plant was significantly higher with 15 November sowing over that of 5 November sown crop. On the other hand, the tiller number was significantly higher with latter date of sowing over 25 October.

\section{Yield attributes}

The effective tillers were comparable in 15 and 5 November sowing and significantly greater over that under 25 October sowing (Table 2). The length of ear head was significantly higher in 15 November sowing over that of 5 November sowing which in turn recorded significantly greater length of ear head over 25 October sown crop. The ear head weight and number of grains per ear head was comparable among 5 and 15 November sown crops and significantly superior over that sown on 25 October. The crop sown on 15 November recorded significantly greater 1000 grain weight over that of 5 November sown crop.

\section{Yield}

Significantly higher grain yield was obtained from 15 November sown crop over that of 5 November and 25 October sown crop (Table 3 ). The decrease in yield in 25 October sown crop was 10.9 and $16.9 \%$ as compared to 5 Nov, 15 Nov sown crop. In the present study, yield and yield components were significantly affected by sowing times. It might be due to cumulative effect of optimum temperature at the vegetative and reproductive stages that provided higher number of fertile tillers plant $^{-1}$, spikelets spike $^{-1}$, and 1000-grain 
weight. Significantly lower yield obtained with crop sown on 25 October can be attributed to lower values of the abovementioned characters due to sub optimal temperature at the early vegetative stage. Patel et al., (2000) has reported that sowing on $15^{\text {th }}$ November resulted in the highest tillers per plant and total biomass at maturity. The improvement in yield attributes and growth in the crop sown in 15 November has resulted in higher grain yield.

The straw yield observed with 15 and 5 November sown crop was comparable with each other and significantly greater than that observed with 25 October sown crop (Table 3).

The harvest index was higher in 15 November sown crop followed by 5 November and 25 October (Table 3).

\section{Varieties}

\section{Growth}

There was no variation in germination/ plant stand at 10 DAS due to varieties. At harvest, the plant height of NDB-2 and NDB-3 was significantly more than NDB-1173 and significantly more than NDB 1173 which in turn recorded significantly higher height over that of super laxmi (Table 1).

At maturity, the tiller number recorded with varieties NDB-2 and NDB-3 was comparable with each other and significantly superior over NDB-1173 which in turn recorded significantly higher number of tillers over super laxmi.

\section{Yield attributes}

The variety NDB-3 has recorded significantly greater number of effective tillers over NDB2 but, the effective tiller number in this variety was comparable with that of NDB1173 (Table 2). Further, the effective tillers with NDB -1173 was at par with that of NDB2. Variety Super laxmi recorded significantly lower number of effective tillers as compared to all other varieties.

Variety NDB-3 recorded significantly higher length of ear head over NDB-2. The ear head length of NDB-2 was significantly greater than NDB-1173 which in turn recorded significantly greater length ear head over variety super laxmi.

The variety NDB-3 recorded significantly higher ear head weight than other three varieties NDB-2, NDB-1173 and super laxmi. The ear head weight of latter three varieties was comparable with each other.

The grain number per ear head observed with varieties NDB 3 and NDB 2 was comparable with each other and significantly superior over NDB 1173 and Super laxmi. The grain number per ear head under latter two varieties was at par with each other.

The 1000 grain weight was significantly higher with NDB 3 variety over that of NDB 2 variety which in turn recorded significantly higher 1000 grain weight over NDB 1173 and Super laxmi. The 1000 grain weight observed in latter two varieties was comparable with each other.

\section{Yield}

The grain yield of NDB 3 was significantly greater over that of NDB -2. The grain yield in the latter variety was significantly higher than that of NDB - 1173 (Table 3). Significantly lower yield was observed with super laxmi (local) as compared to other varieties. The effective tillers were significantly greater in NDB -3 over that of NDB -2 and NDB 1173. Similarly, the yield 
attributing characters like spike length, number of grain per spike were also higher in the former variety NDB 3 over all other varieties. The greater values of growth and yield attributes in NDB 3 variety has resulted significant increase in grain yield in NDB 3 over NDB-2 and NDB-1173 and Super laxmi. Soliman et al., (2011) reported that the barley cultivars producing higher grain and biological yield was due to increase in number of grains and grain weight / spike, grain index, plant height and spike length.

The varieties NDB 2 has recorded significantly higher yield over NDB 1173 due to higher yield attributes and growth parameters in the former variety over that of latter variety thereby there was significantly higher yield in NDB 2. The lowest grain yield was observed in super laxmi which possessed lower yield attributes than all other varieties tested, hence the lower yield than other varieties grown in the experiment.

It has been reported that the genotype of barley with high biomass production, harvest index and number of kernels per spike were important for selecting for improved grain yield (Sintayehu, 2003). Further, the final grain yield of barley is determined by the product of three components: the number of ears per meter square, the number of grains per year, and individual grain weight contribute greatly to crop yield (Garcia et al., 2005). These evidences suggest that the higher yield in the barley varieties is due to superiority of yield attributes of cultivars one over the other and thereby ultimately resulting in higher yields.

Table.1 Effect of different treatments on the plant population meter ${ }^{-1}$ row length of barley

\begin{tabular}{|c|c|c|c|}
\hline Sowing dates (D) & $\begin{array}{c}\text { Initial plant } \\
\text { population per } \\
\text { meter row length }\end{array}$ & $\begin{array}{l}\text { Plant height at } \\
\text { Maturity, cm }\end{array}$ & $\begin{array}{l}\text { Tillers per plant } \\
\text { at Maturity }\end{array}$ \\
\hline 25 October & 42.00 & 91.4 & 9.75 \\
\hline 05 November & 42.17 & 97.1 & 11.09 \\
\hline 15 November & 41.91 & 101.1 & 11.97 \\
\hline S.Em. \pm & 0.17 & 1.0 & 0.21 \\
\hline C.D. at 5\% & NS & 3.8 & 0.83 \\
\hline \multicolumn{4}{|l|}{ Varieties (V) } \\
\hline NDB-2 & 42.04 & 99.6 & 11.29 \\
\hline NDB-3 & 42.16 & 97.0 & 11.66 \\
\hline NDB-1173 & 42.04 & 96.9 & 10.71 \\
\hline $\begin{array}{l}\text { Super Laxmi } \\
\text { (Local) }\end{array}$ & 42.88 & 92.6 & 10.08 \\
\hline S.E m. \pm & 0.10 & 1.2 & 0.17 \\
\hline C.D. at $5 \%$ & NS & 3.5 & 0.51 \\
\hline Interaction $(\mathrm{D} \times \mathrm{V})$ & NS & NS & NS \\
\hline
\end{tabular}


Table.2 Effect of different treatments on yield attributes characters of barley.

\begin{tabular}{|c|c|c|c|c|c|}
\hline Dates of sowing (D) & $\begin{array}{l}\text { Number of } \\
\text { ear-head } \mathbf{m}^{-1} \\
\text { row length }\end{array}$ & $\begin{array}{c}\text { Length of } \\
\text { earhead }(\mathrm{cm})\end{array}$ & $\begin{array}{l}\text { Weight of } \\
\text { earhead (g) }\end{array}$ & $\begin{array}{c}\text { Number of } \\
\text { grains } \\
\text { earhead }^{-1}\end{array}$ & $\begin{array}{c}\text { 1000-grain } \\
\text { weight (g) }\end{array}$ \\
\hline 25 October & 55.73 & 5.89 & 4.44 & 33.58 & 22.68 \\
\hline 05 November & 61.24 & 6.52 & 4.86 & 37.40 & 25.11 \\
\hline 15 November & 63.18 & 6.93 & 5.01 & 38.76 & 26.91 \\
\hline S.Em. \pm & 0.77 & 0.04 & 0.07 & 0.72 & 0.19 \\
\hline C.D. at $5 \%$ & 3.02 & 0.18 & 0.26 & 2.84 & 0.73 \\
\hline \multicolumn{6}{|l|}{ Varieties (V) } \\
\hline NDB-2 & 59.77 & 6.49 & 4.76 & 37.59 & 25.01 \\
\hline NDB-3 & 62.32 & 6.86 & 4.97 & 37.93 & 26.42 \\
\hline NDB-1173 & 60.39 & 6.30 & 4.75 & 35.60 & 24.37 \\
\hline Super Laxmi (Local) & 57.73 & 6.12 & 4.60 & 35.19 & 23.79 \\
\hline S.Em. \pm & 0.83 & 0.05 & 0.06 & 0.63 & 0.24 \\
\hline C.D. at $5 \%$ & 2.46 & 0.16 & 0.18 & 1.87 & 0.71 \\
\hline Interaction $(\mathrm{D} \times \mathrm{V})$ & NS & $\mathbf{S}^{*}$ & NS & NS & $\mathbf{S}^{*}$ \\
\hline
\end{tabular}

Table.3 Effect of sowing dates and varieties on grain and straw yield $\left(\mathrm{kg} \mathrm{ha}^{-1}\right)$ and harvest index $(\%)$ of barley

\begin{tabular}{|c|c|c|c|}
\hline \multirow[t]{2}{*}{ Sowing dates (D) } & \multicolumn{2}{|c|}{ Yield $\left(\mathrm{kg} \mathrm{ha}^{-1}\right)$} & \multirow{2}{*}{$\begin{array}{c}\text { Harvest index } \\
(\%)\end{array}$} \\
\hline & Grain & Straw & \\
\hline 25 October & 3518 & 5457 & 39.20 \\
\hline 05 November & 3947 & 5874 & 40.18 \\
\hline 15 November & 4235 & 5940 & 41.57 \\
\hline S.Em. \pm & 35 & 72 & - \\
\hline C.D. at 5\% & 136 & 281 & - \\
\hline \multicolumn{4}{|l|}{ Varieties (V) } \\
\hline NDB-2 & 3954 & 5800 & 40.48 \\
\hline NDB-3 & 4204 & 6011 & 41.06 \\
\hline NDB-1173 & 3831 & 5739 & 40.03 \\
\hline Super Laxmi (Local) & 3610 & 5479 & 39.71 \\
\hline S.Em. \pm & 34 & 59 & - \\
\hline C.D. at $5 \%$ & 101 & 176 & - \\
\hline Interaction $(\mathrm{D} \times \mathrm{V})$ & $\mathbf{S}^{*}$ & $\mathbf{S}^{*}$ & - \\
\hline
\end{tabular}


Table.4 Interaction effect of sowing dates and varieties on grain and straw yield $\left(\mathrm{kg} \mathrm{ha}^{-1}\right)$ of barley varieties

\begin{tabular}{|c|c|c|c|c|}
\hline \multirow[t]{2}{*}{ Varieties } & \multicolumn{3}{|c|}{ Dates of sowing } & \multirow[t]{2}{*}{ Mean } \\
\hline & 25 October & 05 November & 15 November & \\
\hline \multicolumn{5}{|c|}{ Grain yield } \\
\hline NDB-2 & 3608 & 3864 & 4389 & 3954 \\
\hline NDB-3 & 3642 & 4306 & 4664 & 4204 \\
\hline NDB-1173 & 3633 & 3864 & 3997 & 3831 \\
\hline Super Laxmi (Local) & 3189 & 3753 & 3889 & 3610 \\
\hline Mean & 3518 & 3947 & 4235 & \\
\hline S.Em. \pm & \multicolumn{4}{|c|}{59.0} \\
\hline C.D. at $5 \%$ & \multicolumn{4}{|c|}{175.4} \\
\hline \multicolumn{5}{|c|}{ Straw yield } \\
\hline NDB-3 & 5699 & 6279 & 6056 & 6011 \\
\hline NDB-1173 & 5617 & 5786 & 5813 & 5739 \\
\hline Super Laxmi (Local) & 4889 & 5721 & 5826 & 5479 \\
\hline Mean & 5457 & 5874 & 5940 & \\
\hline S.Em. \pm & \multicolumn{4}{|c|}{103} \\
\hline C.D. at $5 \%$ & \multicolumn{4}{|c|}{305} \\
\hline
\end{tabular}

\section{Interaction of dates of sowing and varieties}

The grain yield was significantly higher when NDB-3 variety was sown on 15 November as compared to all other treatment combinations (Table 4). The grain yield in this treatment was followed by the variety NDB -2 sown on 15 November and NDB-3 sown on 5 November. The grain yield obtained under these two treatments was comparable. Significantly lower grain yield was observed with super laxmi sown on 25 October as compared to all other treatment combinations.

The yield attributes like 1000 grain weight and spike length were higher in the treatment combination of variety NDB 3 sown on 15 November as compared to other treatment combinations. Similarly lowest of these parameters were observed in Super laxmi sown on October 25. The grain yield had positive correlation with yield attributes indication that increase in these parameters has increased the grain yield.
The straw yield recorded with variety NDB -3 sown on 5 November was comparable with that of NDB-2 and NDB-3 sown on 15 November and significantly superior over all other treatment combinations (Table 4). It was significantly lower with variety super laxmi sown on 25 October as compared to all other treatment combinations.

From these results, it can be concluded that for gird region of northern Madhya Pradesh, sowing of barley variety NDB 3 on 15 November gives higher yield.

\section{References}

Alam, M. Z., Haider, S. A. and Paul, N. K. (2006). Growth attributes of barley (Hordeum vulgare L.) cultivars in relation to sowing time. Bangladesh $J$. Bot. 35(2):185-187.

Anonymous (2014). Package of Practices for Rabi Crops. Punjab Agricultural University, Ludhiana, pp. 21-24. 
Garcia Del Moral L.F, Rharrabti, Y, .Elhani, S., Martos V. and Royo. C. (2005). Yield formation in mediterranean durum wheat under two contrasting water regimes based on path-coefficient analysis. Euphytica. 146: 203-212.

Kavitha, G., Dhindsa, G. S., and Singh, S. (2012). Influence of planting time and nitrogen levels on grain quality parameters of barley (Hordeum vulgare L.) genotypes. Journal of Research, 49: 212-215.

Panse, V.G. and Sukhatme, P.V. 1989. Statistical methods for agriculture of workers. $5^{\text {th }}$ Ed. ICAR, New Delhi.

Patel, R.N., Namdeo, K. N. and Tiwari, R.K. (2000). Response of new barley genotypes to nitrogen levels under rainfed condition. Ann. Pl. soil Res. 2(2): 268-269Rashid et al., 2010).

Singh, R.K., and Singh, R.K. (2005). Effect of time and levels of nitrogen application on malt barley (Hordeum vulgare). Indian J Agron, 50: 137-39.

Sintayehu Debebe, (2003) .Variability and associations among yield and yield related traits in barley. An M.Sc. Thesis Presented to the School of Graduate Studies of Alemaya University.

Soliman, A.M. M., El-Bawab, A.M.O. and ElKholy, El-M.A. (2011). Productivity of some barley cultivars under different methods and amounts of irrigation water. International Journal of Academic Research. 3(1):-125-129.

WWW.Farmersfriend.info>Barley

\section{How to cite this article:}

Pawan Shivhare, M. Devender Reddy, Girish Pandey and Anuj Kumar. 2020. Performance of Barley (Hordeum vulgare L.) Varieties to Different Sowing Dates under Irrigated Conditions. Int.J.Curr.Microbiol.App.Sci. 9(04): 2216-2223. doi: https://doi.org/10.20546/ijcmas.2020.904.265 